\title{
SUBJECTIVE WELL BEING PADA GENERASI Z SANTRI PTYQ REMAJA KUDUS
}

\author{
Sirril Wafa dan Yanies Novira Soedarmadi \\ Program Studi Psikologi, Fakultas Bisnis dan Humaniora, Universitas Teknologi Yogyakarta \\ Jl. Siliwangi (Ringroad Utara), Jombor, Sleman D.I Yogyakarta, 55285 \\ E-mail: sirilwafa1997@gmail.com
}

\begin{abstract}
Abstrak
Penelitian ini bertujuan untuk mengetahui subjective well being pada generasi $Z$ santri Pondok Pesantren Tahfidz Yanbu'ul Qur'an Remaja (PTYQR). Metode yang digunakan dalam penelitian ini adalah kualitatif studi kasus intrinsik dengan analisis tematik theory driven. Penelitian ini melibatkan tiga orang partisipan usia 18 tahun berjenis kelamin laki-laki santri Pondok Pesantren Tahfidz Yanbu'ul Qur'an Remaja (PTYQR). Ketiga partisipan memiliki pengalaman yang sama yaitu siswa MA NU TBS Kudus Santri Pondok Pesantren Tahfidz Yanbu'ul Qur'an Remaja (PTYQR). Teknik penggalian data dalam penelitian ini adalah wawancara dan observasi. Hasil penelitian menunjukkan terdapat partisipan yang memiliki pengalaman positif maupun pengalaman negatif. Kedua pengalaman ini dipengaruhi oleh faktor eksternal dan internal dalam diri. Faktor internal yang mendukung adanya pengalaman positif meliputi: adanya motivasi berprestasi yang tinggi, kemampuan partisipan dalam menghadapi beban akademik, adanya cita-cita dan tujuan hidup jelas yang ingin diraih serta perasaan bangga sebagai santri penghafal Al Qur'an. Faktor eksternal yang mendukung adanya pengalaman positif meliputi: adanya support dari orang tua, terjalinnya relasi positif pada partisipan dengan teman dan guru, serta adanya kepuasan dan perasaan bangga terkait kebijakan yang diterapkan Sekolah dan Pondok Pesantren. Pada pengalaman negatif faktor internal yang mendukung meliputi: rendahnya motivasi berprestasi, faktor ketidakmampuan partisipan dalam menghadapi beban akademik serta belum adanya cita-cita dan tujuan hidup yang jelas. Faktor eksternal yang mendukung adanya pengalaman negatif pada partisipan meliputi: kurangnya support dan perhatian dari orang tua, kurang terjalinnya relasi positif antara partisipan dengan teman dan guru, tidak adanya kepuasan terkait kebijakan yang diterapkan Sekolah dan Pondok Pesantren. Dampaknya partisipan yang memiliki pengalaman positif cenderung berperilaku sesuai peraturan di Sekolah dan Pondok Pesantren serta memiliki prestasi akademik yang bagus, sedangkan partisipan yang memiliki pengalaman negatif cenderung memiliki prestasi akademik yang rendah dan berperilaku melanggar aturan di Sekolah maupun Pondok Pesantren.
\end{abstract}

Kata Kunci: Subjective well being, Generasi Z, Santri, Pondok Pesantren

\section{SUBJECTIVE WELL BEING AMONG Z GENERATION OF PTYQ YOUTH KUDUS STUDENTS}

\begin{abstract}
This study aimed to determine the subjective well being of the $Z$ generation of Tahfidz Yanbu'ul Qur'an Adolescent Islamic Boarding School students (PTYQR). The method used in this research is a qualitative intrinsic case study with theory driven thematic analysis. This study involved three participants aged 18 years, male students of the Tahfidz Yanbu'ul Qur'an Youth Islamic Boarding School (PTYQR). The three participants had the same experience, namely MA NU TBS Kudus Santri Pondok Pesantren Tahfidz Yanbu'ul Qur'an Teenagers (PTYQR) students. Data mining techniques in this study were interviews and observation. The results showed that there were participants who had both positive and negative experiences. Both of these experiences are influenced by external and internal factors within oneself. Internal factors that support positive experiences include: the existence of high achievement motivation, the ability of participants to deal with academic burdens, the existence of clear goals and life goals to be achieved and feelings of pride as students who memorize the Qur'an. External factors that support positive experiences include: support from parents, the establishment of positive
\end{abstract}


relationships between participants with friends and teachers, as well as satisfaction and feelings of pride related to policies implemented by schools and Islamic boarding schools. In the negative experience, internal factors that support include: low achievement motivation, the inability of participants to deal with academic burdens and the absence of clear goals and goals in life. External factors that support negative experiences for participants include: lack of support and attention from parents, lack of positive relationships between participants and friends and teachers, lack of satisfaction related to policies implemented by schools and Islamic boarding schools. The impact is that participants who have positive experiences tend to behave according to the rules in schools and Islamic boarding schools and have good academic achievements, while participants who have negative experiences tend to have low academic achievements and behave in violation of rules in schools and Islamic boarding schools.

Keywords: Subjective well being, Generation Z, Students, Boarding School

\section{Pendahuluan}

Generasi $Z$ adalah generasi yang terlahir di situasi perkembangan teknologi yang sangat canggih (digital native), generasi Z lahir di antara rentang tahun 1995 - 2012, generasi Z dicirikan dengan karakteristik digital : seluruh aspek fisik memiliki ekuivalen digital, hiper kustomisasi : generasi $Z$ melakukan penyesuaian diri terhadap perubahan agar bisa tampil dikenal oleh dunia, Realistis : generasi Z memiliki karakteristik cara berpikir yang lebih realistis, Fomo : generasi Z memiliki kecenderungan rasa takut tertinggal informasi dan cenderung memiliki keinginan untuk lebih up to date, Wecomist : generasi Z lebih mengandalkan sistem kerjasama kolektif dalam menjalankan ekonomi, do it yourself : terbiasa melakukan segala sesuatu secara sendiri, terpacu : generasi Z memiliki karakteristik lebih kompetitif (Stillman \& Stillman, 2018). Generasi Z saat ini memasuki usia remaja, tugas perkembangan remaja menurut psikososial erik-erikson sedang memasuki fase pencarian identitas diri, keberhasilan remaja memperoleh gambaran identitas diri dipengaruhi oleh seberapa besar kesempatan remaja mengeksplor dunia sosial guna mengasah pemahaman tentang kemampuan, peran dan tanggung jawab yang dihadapi (Santrock, 2002). Proses pencarian identitas diri yang gagal, menyebabkan remaja mengalami kebingungan akan jati diri, tidak adanya tujuan hidup yang jelas serta kebingungan peran sosial pada remaja, kondisi ini menghasilkan remaja yang terisolir dan tidak mandiri (Santrock, 2002).

Partisipan pada penelitian ini adalah remaja generasi $Z$ santri pondok pesantren. Karakteristik perkembangan santri pondok pesantren sebagai remaja generasi z bercirikan kedekatan dengan teknologi informasi dan interaksi sosial yang tidak terbatas, karakteristik ini bertentangan dengan kurikulum pendidikan di lingkungan pesantren yang masih memegang prinsip tradisional dengan membatasi akses sosial dan akses penggunaan teknologi informasi sebagai media belajar mengajar. Partisipan adalah santri Pondok Pesantren Tahfidz Yanbu'ul Qur'an Remaja (PTYQR) dan siswa di MA NU TBS Kudus, partisipan memiliki kewajiban untuk menghafal Al Qur'an dan kitab klasik sebagai syarat kenaikan kelas. Partisipan juga setiap minggunya dibebani dengan muatan pelajaran lokal, salaf (agama) dan umum di sekolah, dan aturan pembatasan kegiatan sosial, larangan penggunaan akses teknologi informasi, ditambah seluruh santri dan peserta didik di lingkungan partisipan keseluruhan berjenis kelamin laki-laki (Arwaniyyah.com, 2021). Kondisi ini menjadikan tidak terpenuhinya tugas perkembangan partisipan sebagai remaja generasi $Z$ untuk mengeksplorasi lingkungan sosial baik secara langsung maupun melalui akses teknologi informasi.

Dampak dari kebijakan di Pesantren dan Sekolah, peneliti memperoleh temuan melalui wawancara awal, hasilnya terdapat beberapa kasus santri pondok pesantren yang melanggar peraturan, seperti: membolos saat jam pelajaran, merokok, membawa smartphone, pacaran, bertemu lawan jenis secara diam-diam sampai tidur saat jam pelajaran karena merasa kelelahan dengan aktivitas di pondok pesantren yang selesai sampai larut malam. Perilaku melanggar peraturan dilakukan karena santri merasa bosan dengan situasi di pesantren, pada sebagian santri rasa bosan berdampak pada motivasi akademik yang menurun, akibatnya santri menjadi tidak fokus menghafal, sulit memahami pelajaran di sekolah sampai penurunan prestasi akademik dan sebagian santri harus 
tidak naik kelas karena tidak berhasil mencapai target hafalan kitab klasik. Temuan awal ini dipertegas oleh hasil kuesioner the modified BBC subjective well being scale (BBC-SWB) yang di kembangkan oleh Pontin, Schwannauer, Tai dan Kindermen (2013). Alat ukur subjective well being ini mengukur 3 dimensi well being yaitu psychological well being, physical health and well being dan relationship. skala BBC SWB diujikan pada 15 santri pondok pesantren Tahfidz Yanbu'ul Qur'an Remaja kelas 11 MA (SLTA), hasil kuesioner menunjukkan 9 partisipan memiliki tingkat well being yang sangat rendah, dan 6 lainnya memiliki tingkat well being berada di level sedang. Temuan peneliti terkait perilaku santri melanggar peraturan pondok pesantren bertentangan dengan tujuan dari Pondok Pesantren Tahfidz Yanbu'ul Qur'an yang memiliki tujuan mendidik santri menjadi Hafidz Al-Qur'an yang berakhlakul karimah, akhlakul karimah sendiri dicirikan sebagai suatu perilaku yang baik dan terpuji. (Arwaniyyah.com, 2021).

Subjective well being adalah istilah yang digunakan untuk menggambarkan kesejahteraan individu dari hasil evaluasi subjektif kehidupan. (Diener, 2009). Diener \& Tov (2013) mendefinisikan kesejahteraan subjektif sebagai cara individu dalam mengevaluasi pengalaman diri dalam hidup. Sedangkan Diener \& Suh (2000) mendefinisikan subjective well being adalah teori evaluasi dari pengalaman hidup yang telah dialami dengan melibatkan proses kognitif dan afektif secara aktif. Adanya pertentangan antara karakteristik santri pondok pesantren sebagai remaja generasi $Z$ dengan kurikulum pendidikan di lingkungan pesantren, membuat kasus ini semakin kompleks, pada kasus tersebut menghantarkan peneliti ingin melihat bagaimana gambaran subjective well being santri Pondok Pesantren Tahfidz Yanbu'ul Qur'an Remaja (PTYQR) dan faktor yang mempengaruhinya.

Beberapa penelitian telah dilakukan untuk mengetahui hubungan antara subjective wellbeing dengan variabel lainnya pada remaja. Penelitian pertama dilakukan oleh Hamdana dan Alhamdu (2015), yang hasilnya menunjukkan adanya korelasi yang sangat signifikan antara variabel subjective well being dengan prestasi belajar siswa akselerasi MAN 3 Palembang. Lebih lanjut, penelitian lain yang dilakukan oleh Hamdana dan Alhamdu (2015) terkait subjective well-being pada 104 siswa MAN 3 Palembang yang tinggal di asrama menunjukkan bahwa Penelitian tersebut membahas mengenai bagaimana kondisi subjective well being siswa MAN 3 Palembang yang tinggal di asrama serta mencari faktor- faktor yang mempengaruhi subjective well beingnya. Hasil penelitian tersebut menunjukkan kondisi subjective well-being siswa MAN 3 yang tinggal di asrama berada pada posisi moderat (tengahtengah) dengan angka $71,2 \%$. Selain itu peneliti juga menemukan tiga faktor utama yang mempengaruhi kondisi subjective well being positif. Yaitu teman yang menyenangkan serta menumbuhkan kemandirian dan membentuk kedisiplinan. Serta tiga faktor utama yang mempengaruhi kondisi subjective well being negatif, yaitu fasilitas asrama yang masih kurang, kegiatan yang terlalu padat dan monoton, serta pembina yang pemarah. Penelitian yang lain terkait subjective well-being pada remaja dilaksanakan oleh A'yun et., al (2018), yang bertujuan untuk mengetahui gambaran dan faktor-faktor subjective well-being pada remaja perempuan di pondok pesantren dengan metode kajian pustaka. Hasilnya faktor yang mempengaruhi subjective well-being pada remaja perempuan di pondok pesantren yaitu kebebasan, kemandirian, dukungan sosial, tujuan hidup, pengembangan diri, dan status sosial ekonomi.

Telah terdapat beberapa penelitian terkait dengan subjective well-being pada siswa boarding school. Penelitian yang dilakukan Yuliyanto dan Indartono (2019), yang bertujuan untuk mengetahui pengaruh kecerdasan spiritual terhadap kesejahteraan subjektif siswa di SMA Muhammadiyah Boarding School Yogyakarta. Hasil studi ini menunjukkan bahwa kecerdasan spiritual berpengaruh positif dan signifikan terhadap kesejahteraan subjektif siswa di SMA Muhammadiyah Boarding School Yogyakarta sebesar 48\%. Selanjutnya, penelitian yang dilakukan oleh Rahmi et.,al (2019), bertujuan untuk mengetahui dampak akademik resiliensi terhadap kesejahteraan subjektif mahasiswa Islam Pesantren. Hasil penelitian menunjukkan bahwa ada pengaruh akademik resiliensi terhadap kesejahteraan subjektif santri di pondok pesantren. Artinya, semakin banyak resiliensi akademik yang dimiliki oleh siswa, kesejahteraan subjektif juga akan meningkat. Sebaliknya, jika resiliensi akademik menurun maka tingkat kesejahteraan subjektif juga menurun. Lebih lanjut, 
penelitian yang dilakukan oleh Dewi et., al (2021), bertujuan untuk menganalisis model pengaruh keluarga dukungan sosial, rasa syukur, dan penerimaan diri terhadap kesejahteraan subjektif pada santri di Pondok Pesantren. Hasil penelitian ini menunjukkan bahwa dukungan sosial keluarga, rasa syukur, dan penerimaan diri memiliki korelasi positif yang signifikan terhadap kesejahteraan subjektif.

Di sisi lain, keunikan pada penelitian ini bertujuan menggambarkan aspek subjective well being dan faktor yang mempengaruhinya melalui pendekatan kualitatif studi kasus, kemudian mengaitkannya dengan karakteristik perkembangan remaja sebagai generasi $Z$ santri pondok pesantren tahfidz tradisional. Partisipan dan lokasi penelitian menjadi isu yang baru dibahas karena belum terdapat tema penelitian well being di Pondok Pesantren Tahfidz Yanbu'ul Qur'an Remaja (PTYQR) dengan mengadopsi teori subjective well being dari tokoh Diener.

\section{Metode Penelitian}

Metode dalam penelitian ini menggunakan pendekatan kualitatif, pendekatan ini bertujuan untuk menggambarkan fenomena subjective well being pada generasi Z santri Pondok Pesantren Tahfidz Yanbu'ul Qur'an Remaja secara deskriptif (Sugiyono, 2015). Jenis penelitian ini adalah studi kasus intrinsik, jenis penelitian intrinsik dipilih karena keunikan kasus dengan tujuan tidak melakukan generalisasi terhadap kelompok partisipan. Penelitian ini didasari pada ketertarikan peneliti terhadap isu subjective well being generasi $Z$ santri pondok pesantren. Pengambilan sampel dalam penelitian ini menggunakan purposive sampling, teknik purposive sampling menurut Neuman (2013) adalah teknik menentukan sampel penelitian dengan merumuskan kriteria terlebih dahulu. Kriteria partisipan pada penelitian ini adalah remaja akhir, berjenis kelamin laki-laki usia 16-18 tahun santri Pondok Pesantren Tahfidz Yanbu'ul Qur'an Remaja kelas XI di MA NU TBS Kudus berjenis kelamin laki-laki dengan syarat minimal lama mondok adalah 1 tahun. Penelitian ini melibatkan 3 partisipan. Partisipan pertama berasal dari Kota Kudus, partisipan 2 berasal dari luar Jawa dan partisipan 3 berasal dari luar kota Kudus.

\section{Partisipan Penelitian}

Partisipan pada penelitian ini berjumlah 3 orang Santri Pondok Pesantren Tahfidz Yanbu'ul Qur'an Remaja (PTYQR). Tekhik pemilihan partisipan menggunakan metode purposive sampling, menurut Neuman (2013). Purposive sampling merupakan salah satu teknik pengambilan sampel dengan mempertimbangkan kriteria tertentu.

Kriteria partisipan penelitian ini yaitu:

1. Berjenis kelamin laki-laki.

2. Santri Pondok Pesantren Tahfidz Yanbu'ul Qur'an Remaja (PTYQR) dengan lama mondok minimal 1 tahun dan sedang menempuh pendidikan formal di MA NU TBS Kudus.

3. Usia $16-18$ tahun

Penentuan kriteria partisipan tersebut didasarkan karena Santri Pondok Pesantren Tahfidz Yanbu'ul Qur'an Remaja (PTYQR) dan siswa MA NU TBS Kudus secara keseluruhan berjenis kelamin laki-laki, partisipan memiliki kewajiban akademik untuk menghafal Al Qur'an 30 Juz, menghafal kitab klasik sebagai prasyarat kenaikan kelas dan adanya tambahan muatan pendidikan lokal dan salaf yang membuat beban pelajaran partisipan cukup banyak dibanding sekolah pada umumnya, selain itu di lingkungan sekolah dan Pondok Pesantren memperlakukan larangan mengakses hand phone, melakukan interaksi dengan lawan jenis bukan keluarga dan pembatasan kegiatan di luar jam pelajaran Sekolah dan Pondok Pesantren (Arwaniyyah, 2021 ; Ma Nu Tbs Kudus.sch, 2021 ; Siap-Sekolah.Com, 2021). Menurut Diener \& Suh, (2000) kemampuan individu dalam mengevaluasi kondisi hidup di pengaruhi adanya pengalaman hidup yang dijalaninya. Kondisi tersebut menjadi dasar penentuan kriteria partisipan minimal memiliki pengalaman menjadi santri selama 1 tahun. Penentuan kriteria 
umum 16 - 18 tahun merujuk pada usia rata-rata peserta didik di tingkat SLTA sebagai generasi Z (Kemdikbud, 2021; Stillman \& Stillman, 2018).

Proses penemuan partisipan diawali dengan observasi dan wawancara terkait kasus santri melanggar aturan Pesantren dan Sekolah. Selanjutnya peneliti menjalin rapport dengan pengurus Pondok Pesantren, sebagai tindak lanjut peneliti meminta kesediaan pengurus untuk melakukan penelitian di pondok pesantren dan meminta kesediaan 3 partisipan dalam mengikuti rangkaian penelitian untuk diwawancarai dengan ditandatanganinya informed consent sebagai bukti kesediaan sebagai partisipan penelitian. Data penelitian dikumpulkan melalui wawancara semi terstruktur dan observasi partisipan. Wawancara semi terstruktur dilakukan dengan panduan pertanyaan terbuka. Observasi partisipan dilakukan untuk memperoleh data pendukung terkait well being partisipan. Wawancara terhadap ketiga partisipan dilakukan di lingkungan pondok pesantren sebanyak tiga kali setiap partisipan, data dikumpulkan secara bergilir antara satu partisipan ke partisipan lainnya. Serta melakukan cross check dengan mewawancarai 3 significant other, significant other partisipan 1 adalah teman sebangku partisipan, significant other 2 adalah teman satu kamar partisipan, significant other 3 adalah teman dekat partisipan.

\section{Metode Pengumpulan Data}

Metode pengumpulan data pada penelitian ini menggunakan metode wawancara dan observasi, wawancara pada penelitian ini menggunakan jenis wawancara semi terstruktur, wawancara semi terstruktur adalah wawancara yang menggunakan pedoman umum sebagai panduan pertanyaan penelitian agar sesuai dengan topik bahasa dan kemudian mengembang pertanyaan penelitian sesuai kebutuhan (Fudyartanta, 2017). Observasi Penelitian ini menggunakan jenis observasi non partisipan tidak terstruktur, penelitian non partisipan memposisikan diri sebagai pengamat dan tidak ikut serta dalam kegiatan partisipan, dengan pengamatan penelitian tidak menggunakan instrumen yang baku, tetapi hanya berupa rambu-rambu pengamatan (Fudyartanta, 2017). Metode pencatatan observasi pada penelitian ini menggunakan metode naratif dengan mendeskripsikan temuan observasi.

Proses pengumpulan data dilakukan melalui wawancara mendalam dan observasi kepada partisipan. Wawancara semi terstruktur dilaksanakan untuk memperoleh data dari partisipan secara langsung dan didukung oleh hasil wawancara kepada ketiga significant other, dan temuan observasi non partisipan. Wawancara dilaksanakan di pondok pesantren. Data hasil wawancara dikumpulkan secara bergilir dengan bantuan voice recorder setelah memperoleh persetujuan dari partisipan. Hasil voice recorder selanjutnya disajikan menjadi data transkrip wawancara kualitatif, hasil transkrip kemudian dianalisis secara berulang dan spesifik untuk memperoleh kategori pernyataan partisipan yang bermakna (Liamputtong, 2009). Analisis data bertujuan untuk memperoleh informasi gambaran dan faktor yang mempengaruhi subjective well being pada santri Pondok Pesantren Tahfidz Yanbu'ul Qur'an Remaja (PTYQR) Kudus. Upaya untuk memperoleh konsistensi dan kebenaran data, peneliti melaksanakan triangulasi data dengan mewawancarai sebanyak tiga kali pada setiap partisipan dan melakukan konfirmasi keabsahan data melalui wawancara ke significant other, observasi ke partisipan serta penelusuran dokumen yang relefan untuk mendukung validitas data. (Neuman, 2013).

\section{Analisis Data}

Hasil wawancara yang diperoleh selanjutnya diolah secara kualitatif, dianalisis secara spesifik dengan membaca transkrip secara berulang dan menemukan konsep dan kategori-kategori pernyataan yang bermakna. (Liamputtong, 2009). Data dianalisis secara spesifik untuk mengetahui kondisi well being santri Pondok Pesantren Tahfidz Yanbu'ul Qur'an Remaja (PTYQR) dan faktor yang mempengaruhinya, Peneliti melakukan triangulasi terhadap data itu sendiri dan dengan sumbersumber berbeda, melalui wawancara lanjutan untuk memperoleh konfirmasi atas data sebelumnya. Analisis pada penelitian ini menggunakan jenis analisis tematik dengan jenis pengembangan kode dari pendekatan theory-driven. Analisis tematik jenis theory-driven adalah pendekatan yang sering 
digunakan dalam penelitian sosial pendekatan kualitatif. Analisis data dimulai dengan pembahasan dari teori tertentu, kemudian mencari temuan kasus yang mendukung teori tersebut. (Boyatzis, 1998).

Tabel 1. Data demografi partisipan

\begin{tabular}{|c|c|c|c|c|c|c|}
\hline \multicolumn{7}{|c|}{ Identitas Partisipan } \\
\hline No & Partisipan & Usia & Jenis Kelamin & Kelas & Asal Daerah & Lama Mondok \\
\hline 1. & MLA & 17 tahun & laki-laki & $\begin{array}{l}11 \text { MA NU } \\
\text { TBS Kudus } \\
\text { (SLTA) }\end{array}$ & Kudus & $\begin{array}{l}1,5 \text { tahun sejak kelas } \\
10 \text { (SLTA) MA NU TBS } \\
\text { Kudus }\end{array}$ \\
\hline 2. & AFL & 17 tahun & laki-laki & $\begin{array}{l}11 \text { MA NU } \\
\text { TBS Kudus } \\
\text { (SLTA) }\end{array}$ & Luar Jawa & $\begin{array}{l}4,5 \text { tahun sejak kelas } 7 \\
\text { MTS (SLTP) di MTS NU } \\
\text { TBS Kudus }\end{array}$ \\
\hline 3. & $\mathrm{AHA}$ & 17 tahun & laki-laki & $\begin{array}{l}11 \text { MA NU } \\
\text { TBS Kudus } \\
\text { (SLTA) }\end{array}$ & Luar Kota & $\begin{array}{l}4,5 \text { tahun sejak kelas } 7 \\
\text { MTS (SLTP) di MTS NU } \\
\text { TBS Kudus }\end{array}$ \\
\hline
\end{tabular}

Hasil

Berdasarkan hasil analisis data yang telah dilakukan, didapatkan tema-teman berikut:

\section{Tema Pengalaman positif}

Partisipan 1 berasal dari keluarga religius, ayah partisipan adalah guru dan tokoh agama, partisipan memutuskan menjadi santri penghafal Al Qur'an atas keinginan sendiri sejak kelas 10 SLTA, partisipan yakin dengan menghafal Al Qur'an akan memperoleh keistimewaan kelak di akhirat dan membuat keluarganya bangga. Partisipan setiap harinya menghafal Al Qur'an sampai larut malam di pesantren, saat ini partisipan mampu hafal $19 \mathrm{Juz}$ Al Qur'an hanya dalam kurun waktu satu tahun. Di sekolah partisipan memperoleh rangking 1 di kelas dan paralel jurusan IPA, partisipan beberapa kali memenangkan kejuaraan lomba sains tingkat kabupaten kota, partisipan juga selalu tepat waktu dalam menyelesaikan hafalan kitab di sekolah. Partisipan menikmati pelajaran salaf (agama) di sekolah, dengan memahami ilmu agama partisipan menjadi lebih tau mana yang boleh dan tidak untuk dilakukan, di sekolah partisipan dikenal disiplin dengan datang tepat waktu. Capaian dan kebiasaan tersebut disampaikan partisipan karena cita-cita kelak menjadi rektor di sebuah perguruan tinggi yang mampu menghafal Al Qur'an. Sebagaimana yang disampaikan partisipan dalam pernyataannya :

"bapak kerjanya guru di madrasah mas, bapak juga mendukung mas soal keinginan saya untuk mondok, awalnya mondoknya mau mulai kelas 1 MTS, karena tidak ada respon sama bapak, akhirnya baru kesampaian di kelas 10 MA ini mas"

"Keinginan mondok memang berasal dari diri sendiri, awalnya itu saya pernah dengar ceramah kalo penghafal Al Qur'an kelak itu bisa menolong tujuh turunan keluarganya kelak di akhirat. Akhirnya disetujui bapak pas kelas sepuluh MA ini"

"Alhamdulillah, sekarang sudah hafal $19 \mathrm{Juz}$, untuk di sekolah sekarang saya rangking 1 di kelas, jurusan IPA, bisa rangking 1 itu ya berkat setoran hafalan selalu lebih awal, di tahap 1 terus mas" 
"Untuk sekolah disini, awalnya memang keinginan sendiri, terus kalo di rumah banyak di ajari bapak di pelajaran agama, soalnya bapak juga ngajar pelajaran itu, kayak nahwu shorof"

"saya senang nya di sekolah ini tu memang sudah terpandang di Kudus kan, terkenal banyak mencetak tokoh agama, terus pelajarannyakan banyak ilmu agama, kitab kuning, jadi saya makin seneng di sini mas, soalnya di keluarga besar saya itu belum ada yang masuk sini, terus yang jadi santri penghafal al qur'an itu masih belum ada, keinginan saya lebih ingin membuat bangga orang tua sama keluarga sih mas"

Partisipan 2 memutuskan menjadi santri pondok pesantren atas paksaan orang tua, awalnya partisipan tidak setuju dengan pilihan sekolah di pondok pesantren, setelah beberapa waktu, partisipan merasa bangga menjadi penghafal Al Qur'an, meski pada awalnya sempat menolak. Ayah partisipan bekerja sebagai kontraktor dan Ibu sebagai ibu rumah tangga, kakak laki-laki partisipan telah terlebih dahulu mondok di pesantren. Meski sempat mengalami kesulitan adaptasi bahasa dan budaya. Sebagaimana yang disampaikan partisipan dalam pernyataannya:

"awalnya saya maunya sekolah di daerah sendiri mas, ndak di Jawa", ya bagaimana lagi, bapak ibu memaksa saya kesini, akhirnya saya manut-manut saja"

"Selama di rumah saya kan sudah les hafalan ngaji mas, jadi pas di pondok udah biasa sama hafalan, ngak ada masalah soal hafalan kalo saya, saya itu seneng kalo disuruh menghafal malah mas"

Waktu awal di pondok agak aneh aja gitu, harus pakai sarung taip hari, terus kalo di sekolah pakai peci, belum cuaca yang panas, terus di kelas kok laki-laki semua, guru sama anak kelas lain juga sama laki-laki semua, awalnya saya juga bingung, ngak tau juga, ternyata sekolah ini khusus laki-laki semua"

"Saya sekolah disini awalnya ndak tau kok siswanya cowo semua, kan saya dari SMP negri mas, jadi agak kaget gitu awalnya, awalnya sih merasa terpaksa sekolah jauh jauh ke jawa, terus ndak ada saudara lagi, seiring waktu Alhamdulillah bisa ngerti dikit dikit Bahasa jawa, terus sayakan sudah biasa menghafal kalo di rumah sama guru ngaji, jadi untuk hafalan saya ndak ada masalah"

Partisipan saat ini telah berhasil menyelesaikan hafalan Al Qur'an sejak kelas 9 SLTP, partisipan menyelesaikan hafalan dalam kurun waktu 2 setengah tahun. Di sekolah, partisipan dikenal sebagai pribadi yang taat aturan, tekun belajar dan cenderung pendiam, saat ini partisipan memperoleh rangking 1 di kelas dan rangking 3 Paralel di Jurusan IPA, mata pelajaran yang disukai partisipan terkait ilmu sains dan eksak, setiap tahunnya partisipan mampu menghafal kitab (salaf) di sekolah dengan tepat waktu, cita-cita partisipan ingin menjadi Dokter dan hafidz Al Qur'an. Capaian hasil belajar ini, dipertegas dengan temuan peneliti melalui wawancara ke significant other teman satu kelas partisipan dan melalui penelusuran dokumen hasil belajar di sekolah dan pesantren. Sebagaimana yang disampaikan partisipan dalam pernyataannya :

"Sekarang sudah hafal 30 juz, sejak kelas 9 MTS, faktor orang tua sering nelpon, ngasih semangat, ngingetin tujuan mondok" 
"Pelajaran yang di sukai lebih ke penjurusan MIPA mas, kedepannya orang tua inginnya aku masuk kedokteran"

"karena harapan bapak ibu si mas, tapi saya sendiri ya suka sama pilihan orang tua"

"saya di Kelas IPA Mas, kalo rangkingnya di kelas alhamdulillah rangking 1, tapi paralelnya saya masih kalah mas, Cuma dapet rangking 3 di jurusan IPA"

"Dia memang dikenal pinter mas kalo di pondok, kalo malam itu sering ngak tidur, ngapalin Al Qur'an sendiri, terus kalo di sekolah itu memang disiplin, ngak-ngak pernah tidur kalo di kelas, masuk terus jarang banget dia bolos kayak anak-anak lainnya"

"Dia sudah khatam sejak kelas 9 MTS Mas, di MA sekarang tinggal mengingat hafalan, beda kaya yang lain harus masih menghafal"

Partisipan 3 awalnya ingin melanjutkan pendidikan di sekolah Negeri. Namun karena paksaan orang tua akhirnya ia mau menjadi santri pondok pesantren. Setelah menjadi santri, partisipan awalnya mengalami kesulitan menghafal Al Qur'an, namun setelah dijalani partisipan berhasil menghafal $15 \mathrm{Juz}$, keberhasilan tersebut menurut partisipan tidak terlepas dari dorongan dari orang tua, adanya support dari teman-teman di pesantren. Keberadaan teman dirasa sangat penting menurut partisipan, karena keberadaan teman tersebut partisipan memiliki tempat untuk bercerita jika mengalami permasalahan. Partisipan menjadi tidak merasa sendiri lagi karena selama di pesantren ia memiliki banyak teman, partisipan mengaku bangga menjadi santri penghafal AI Qur'an, sebab menurutnya tidak semua orang memperoleh kepercayaan bisa menghafal Al Qur'an. Kelak setelah lulus partisipan ingin melanjutkan studi di timur tengah, ia ingin memperdalam pengetahuan agama yang dimiliki disana. Sebagaimana yang disampaikan partisipan dalam pernyataannya:

"Yaa awal mulanya sii terlihat susah untuk menghafalnya, tapi setelah kita jalanin ya alhamdulillah bisa, tapi ya itu mas, agak lambat hafalan saya, soalnya awalnya dulu saya maunya sekolah tidak disini, karena dinasehati orang tua terus ya akhirnya saya ngikut saja, sekarang saya hafalannya baru 15, 15 Juz, padahal mondok sudah hampir 5 tahun".

"Enaknya disini banyak teman mas, yaa walaupun cowok semua, setidaknya temantemen saya pada mendukung, suka saling cerita kalo ada masalah".

"Rasanya, Alhamdulillah jadi orang pilihan, bisa menghafal Al Qur'an di usia remaja kayak gini, setelah lulus masih bingung mau kemana, terlalu banyak opsi, tapi yang jelas salah satu mimpi saya mau kuliah di luar negri, belajar agama di timur tengah".

Disimpulkan pengalaman positif ketiga partisipan karena adanya kepuasan dan rasa bangga sebagai santri penghafal Al Qur'an, kepuasan tersebut menjadi semakin baik jika ketiga partisipan berhasil menyelesaikan tugas akademik. Sedangkan motivasi awal ketiga partisipan menjadi penghafal Al Quran sebab keinginan sendiri dan sebagian karena keinginan kedua orang tua. Setelah berhasil menghafal Al Qur'an ketiga partisipan memiliki keinginan menjadi pemuka agama dan melanjutkan pendidikan sampai jenjang perguruan tinggi.

\section{Tema Pengalaman Negatif}

Partisipan 1 merasa tidak setuju dengan aturan pesantren dan sekolah yang melarang santrinya membawa smartphone, partisipan menganggap dengan mengakses media sosial dan bermain smartphone sebagai salah satu caranya untuk menghibur diri ketika sedang merasa jenuh 
dengan rutinitas pesantren. la mengaku dengan bermain smartphone tidak mempengaruhi performa dan motivasi akademiknya. Sebaliknya ia merasa lebih semangat setelah bermain smartphone. Sebagaimana yang disampaikan partisipan dalam pernyataannya:

"Kadang kalo lagi bingung mau ngapain di pondok ya main hp mas, mainnya di luar pas lagi ke warung, itupun diem-diem, soalnya kalo ketahuan pengurus bisa disita"

"Peraturannya sih baik menurutku, tapi kalo dipikir-pikir kadang ndak terima sama aturan pondok sama sekolah, soalnya saya bingung mau cari hiburannya kemana kalo lagi di kurung di pondok. Kalo main hp kan enak mas bisa liat liat berita sepak bola, main game pokoknya buat hiburan kalo lagi susah menghafal juga"

Pengalaman negatif partisipan 2 dirasakan saat awal masuk pondok pesantren sebagai proses adaptasi. Partisipan sempat kaget dengan kondisi lingkungan pendidikan yang diisi oleh laki-laki baik peserta didik, ustadz/guru sampai karyawan. Pengalaman negatif dipengaruhi oleh paksaan orang tua yang membuat partisipan harus masuk ke pondok pesantren. Sebagaimana yang disampaikan partisipan dalam pernyataannya:

"Sedihnya pas lagi awal masuk pondok mas, kelas 1 MTS, awalnya kan aku maunya sekolah di tempat aku sendiri, bukan di Jawa, lbu sering nunjukin poto sekolah yang sekarang di Hp, akhirnya lama kelamaan tertarik, ya awalnya inginnya sih sekolah di SMP Negeri"

"Sempet kaget juga, aku kan ndak ada dikasih tau ternyata muridnya cowok semua, di pondok apalagi juga sama, guru semua disini cowok semua, awalnya kaget, bingung, tapi lama kelamaan bisa adaptasi menyesuaikan lah sama yang lainnya, sama Bahasa Jawa juga sedikit-sedikit belajar"

Beban pelajaran yang banyak sering membuat partisipan 3 merasa kesulitan untuk membagi waktu belajar, khusus pada pelajaran agama partisipan seringkali merasa kesulitan untuk memahaminya. Jam pesantren yang padat seringkali membuat partisipan cepat merasa lelah dan tidak sempat untuk belajar. Partisipan mengalami masalah untuk membagi waktu belajar dan menghafal, faktor gaya mengajar guru juga ikut mempengaruhinya, karena merasa kesulitan memahami pelajaran, partisipan melampiaskannya pada perilaku melanggar aturan pesantren dan sekolah, seperti membolos, tidur saat jam pelajaran, merokok sampai membawa smartphone diam-diam ke pesantren. Perilaku tersebut menurut partisipan awalnya karena ajakan teman di sekolah. la mengaku setelah melakukan hal tersebut ia merasa jauh lebih tenang dan bahagia, meskipun ia tahu perilakunya tersebut telah melanggar aturan, partisipan seringkali merasa bersalah setelah melakukan hal tersebut. Sebagaimana yang disampaikan partisipan dalam pernyataannya :

"Kalo saya itu ndak terlalu anu ndak terlalu opo sih gak terlalu semangat buat di sekolah itu kurang saya, soalnya pelajaran di sini banyak banget mas belum dengan kegiatan pondok yang padet"

"Hasilnya Yak kayak di pelajaran atau ndak terlalu apa namanya opti apa namanya optimal, asal masuk kelas aja, wong saya tidak paham, belum lagi kalau sama guru yang 
tidak sreg, biasanya aku tinggal bolos keluar, akhirnya yak kalo buat semangat di sekolah itu kurang kaya semangat gitu"

"Yaa dari berjalanya waktu itu jadinya sekarang banyak ketinggalannya pelajaran terus dari faktor-faktor lain lah"

"di sekolahan kegiatan seperti biasanya gitu mas, seperti yang lain paling belajar, kalo sudah males ya tidur ya gitu, kalo di pondok banyak gitu mas di pondok juga soalnya saya pengurus di pondok, jadinya mudah capek,kalo lagi capek itu langsung kayak males"

"Kalo emang gurunya itu udah nggak baik-baik lah gitu, suka memaksa, ngak mau ngertiin muridnya, kadang saya tinggal tidur, pas waktu jam kosong gitu, jam kosong kalo ngak emang udah males udah ngak pengen apa-apa baru keluar gitu"

"faktor yang paling mempengaruhi ya itu cuman itu punya soalnya saya pengen keluar gitu aja mas pengen keluar udah males udah gak ada semangat di sekolah gitu akhirnya keluar aja lah daripada di kelas ngak paham pelajaran"

"Nahwu Shorofnya itu belum, belum menguasai gitu mas, sulit pelajarannya, terus dari faktor ketika langsung disini kan langsung loncat alfiyyah gitu alfiyyah padahal sebelumnya juga belum jurumiyyah imrithi sebelumnya jadi ya terlalu ketinggalan"

"awalnya emang sama gurunya emang kurang enakan sedikit, kayak Pak M*, penjelasannya itu penjelasannya kurang enak aja gitu mas"

"dari penjelasan terlalu cepat terus terlalu menekan juga maksudnya harusnya ini harusnya ini, akhirnya ya sedang males akhirnya tidur, bolos pergi ke warung atau kalo ngak berani sama gurunya akhirnya ditinggal ngelamun sendiri di tinggal ngobrol sama temen seperti itu"

Disimpulkan pengalaman negatif ketiga partisipan disebabkan oleh adanya aturan pesantren yang membatasi kebebasan ketiga partisipan, dampaknya partisipan melanggar aturan pesantren dengan cara membolos, merokok, membawa smartphone, mengakses media sosial, pacaran. Pengalaman negatif ketiga partisipan juga dipengaruhi oleh beban akademik yang di rasa berat dengan harus menghafal Al Qur'an, menghafal Kitab sebagai syarat kenaikan kelas, banyaknya jumlah mata pelajaran yang diajarkan dan padatnya kegiatan akademik saat di sekolah dan pesantren, akibatnya ketiga partisipan merasa bosan dan terkekang dengan jadwal kegiatan yang dirasa monoton.

\section{Tema Kepuasan Hidup}

Partisipan 1 memperoleh dukungan dari kedua orang tuanya untuk melanjutkan pendidikan di Pondok Pesantren, meski suka melanggar aturan pesantren, partisipan mengaku paham bahwa semua aturan di pesantren memiliki tujuan yang bagus, namun karena faktor pengaruh teman subjek sering melanggar aturan agar bisa bergaul dengan banyak orang, meski demikian situasi tersebut tidak mempengaruhi prestasi akademik partisipan. Sebab partisipan merasa bangga dapat melanjutkan pendidikan dan belajar ilmu agama. Sebagaimana yang disampaikan partisipan dalam pernyataannya

"Saya mondok disini ya juga karena ada dukungan bapak - ibu mas, kalo saya renungi lagi tujuan adanya peraturan di pondok ya baik, melatih santrinya biar disiplin, fokus 
belajar, ndak banyak main terus menghindari dosa, kayak ketemu lawan jenis, main hp sampai lupa waktu, soalnya banyak teman saya yang kayak gitu"

"Sebagai santri saya bangga mas, bisa menghafal Al Qur'an, jarang-jarang orang seusia saya menghafal Al Qur'an, tempatnya juga nyaman kebutuhan terpenuhi untuk hafalan di sekolah sama pondok Alhamdulillah lancer, selesai tepat waktu"

Faktor support dari keluarga memiliki peranan dalam meningkatkan motivasi belajar partisipan 2, meskipun keputusan menjadi santri pondok pesantren awalnya atas paksaan orang tua. Kepuasan terhadap sekolah ditunjukkan adanya rasa bangga menjadi santri penghafal Al Qur'an, meski partisipan tidak setuju terhadap aturan di pondok pesantren. Kepuasan terhadap relasi sosial partisipan ditunjukkan dengan adanya relasi sosial yang positif dengan teman di sekolah dan pesantren. Sebagaimana yang disampaikan partisipan dalam pernyataannya :

"Di sini yang buat seneng itu temen mas, banyak temannya bisa diajak kemana-mana, bisa cerita juga kalo ada masalah, kalo untuk aturan memang kurang setuju, tapi bisa jadi penghafal Al Qur'an, saya sudah merasa bersyukur sekali, keluarga juga mendukung, tidak banyak menuntut, cuma nasehati kalo pas lagi sambangan".

Partisipan 3 merasa telah berhasil mewujudkan harapan kedua orang tua sebagai santri penghafal Al Qur'an, meski pada kenyataannya partisipan mengalami penurunan motivasi akademik, kondisi ini dipengaruhi oleh ketidakpuasan partisipan terhadap aturan yang diberlakukan di pesantren seperti : larangan membawa smartphone, pembatasan kegiatan sosial, dan lingkungan pendidikan yang dianggap monoton karena berisi laki-laki semua. Kondisi ini diperparah karena ketidakpuasan partisipan terhadap guru pengajar, yang dianggap tidak mampu memahami kondisinya dan kemampuan mengajar yang buruk. Sebagaimana yang disampaikan partisipan dalam pernyataannya :

"Kalo sekarang sih, sudah agak lega bisa mewujudkan harapan orang tua jadi santri penghafal Al Qur'an, tapi ya Cuma itu mas kalo boleh usul ya aturan disini kadang saya kurang setuju, dilarang ini itu lah, kayak di penjara, terus sama beberapa guru di sekolah, kurang bisa ngerti siswanya, kadang cuma disuruh-suruh terus, ngejelasinnya cepat, jadi suka gak paham".

Disimpulkan, kepuasan hidup ketiga partisipan akan terwujud jika mereka berhasil menyelesaikan tanggung jawab akademik, meliputi : menghafal Al Qur'an dan kitab klasik sebagai syarat kenaikan kelas. Kepuasan hidup akan jauh lebih baik pada sebagian partisipan yang memperoleh prestasi akademik dengan memperoleh peringkat di kelasnya. Kepuasan hidup juga terjadi sebab ketiga partisipan merasa telah mewujudkan keinginan kedua orang tuanya untuk menjadi penghafal Al Qur'an 


\section{Pembahasan}

Remaja yang berhasil menemukan identitas diri, ditandai dengan adanya kemampuan untuk memahami diri secara otentik, mengenali karakteristik apa yang membuat diri senang dan tidak, serta mampu menentukan apa yang ingin diperoleh di masa mendatang. (Desmita, 2005). Remaja sebagai generasi $\mathrm{Z}$ memiliki beberapa karakteristik khas, diantaranya a) Percaya diri dan berani dalam mengambil sikap. b) multitasking. c) memiliki hubungan sosial yang luas melalui akses media sosial d) cepat dalam mengakses informasi dan cenderung up to date terhadap informasi terbaru (Bencsik, Csikos dan Juhasz, 2016; Nagy dalam Csobanka, 2016).

Partisipan penelitian ini adalah remaja generasi Z santri Pondok Pesantren, setiap harinya kehidupan partisipan telah diatur secara teratur mulai bangun sampai kembali tidur. Karakteristik kebijakan di Pondok pesantren cenderung bertolak belakang dengan karakteristik perkembangan remaja sebagai generasi Z. Di Pondok Pesantren, partisipan tidak diperbolehkan mengakses teknologi informasi seperti smartphone maupun media sosial serta adanya pembatasan jangkauan interaksi sosial dengan lawan jenis. Disisi lain beban akademik partisipan di pesantren dan sekolah cukup banyak, partisipan harus menyelesaikan muatan pelajaran lokal, umum dan agama selama di sekolah dengan kewajiban menghafal 100 bait kitab klasik sebagai syarat kenaikan kelas. Saat di pesantren partisipan memiliki kewajiban menghafal Al Qur'an. Sedangkan menurut Stillman \& Stillman, (2018) generasi Z memiliki kemampuan lebih dalam mengoperasikan teknologi informasi dan luasnya jangkauan interaksi dan akses informasi tidak terbatas. Kaitannya pada temuan penelitian, terdapat keberagaman gambaran kesejahteraan pada santri Pondok Pesantren Tahfidz Yanbu'ul Qur'an Remaja. Pada partisipan mengalami pengalaman hidup di pesantren secara positif dan negatif. Pengalaman tersebut disebabkan oleh faktor internal dan eksternal diri.

Partisipan yang memiliki pengalaman positif disebabkan adanya rasa bangga bisa menjadi santri penghafal Al Qur'an, kebanggan ini disebutkan partisipan karena masih sangat jarang jumlah penghafal Al Qur'an terlebih pada usia remaja, partisipan merasa menjadi manusia pilihan untuk menjaga Al Qur'an melalui cara menghafalnya. Pengalaman positif ini semakin kuat dengan ditandai dengan keberhasilan partisipan dalam menghafal Al Qur'an, adanya motivasi untuk berprestasi, dukungan dari kedua orang tua serta adanya relasi positif yang dijalin partisipan dengan teman dan guru (ustadz).

Keberhasilan partisipan dalam menghafal Al Qur'an sebab adanya dorongan untuk membahagiakan orang tua dengan mewujudkan cita-cita menjadi seorang penghafal Al Qur'an (tahfidz) serta keinginan untuk menjadi pemuka agama. Tujuan tersebut kemudian menjadi motivasi ketiganya untuk menyelesaikan hafalan Al Qur'an. Temuan ini di dukung oleh Diener, Lucas, \& Oishi, (2002), Diener et.,al yang mengungkapkan bahwa individu yang memiliki well being akan cenderung mempunyai rasa percaya diri yang bagus dan akan lebih produktif dalam menjalani hidup, Ini ditunjukkan pada partisipan yang memiliki pengalaman positif cenderung memiliki prestasi akademik yang lebih baik serta adanya tujuan hidup yang jelas untuk diraih.

Pengalaman negatif ketiga partisipan karena adanya rasa tidak setuju terhadap kebijakan yang diterapkan di Pesantren dan Sekolah, aturan tersebut menurut partisipan hanya membatasi kebebasan partisipan, sedangkan partisipan membutuhkan hiburan jika sedang merasa bosan dengan rutinitas pesantren. Dampaknya partisipan akan mencari celah untuk mencari hiburan meski cara tersebut sebenarnya melanggar kebijakan pesantren. Beberapa perilaku yang dilakukan meliputi bolos di jam pelajaran, merokok, membawa smartphone, mengakses media sosial, sampai tidur saat jam pelajaran.

Pengalaman negatif ketiga partisipan juga dipengaruhi oleh beban akademik yang di rasa berat dengan harus menghafal Al Qur'an maupun menghafal Kitab klasik sebagai syarat kenaikan kelas, banyaknya jumlah mata pelajaran serta padatnya kegiatan akademik saat di sekolah dan pesantren seringkali membuat partisipan merasa kelelahan dan kesulitan untuk memahami dan mengatur waktu belajar, akibatnya ketiga partisipan merasa bosan dan terkekang dengan jadwal kegiatan yang dirasa monoton. Kurangnya support dari orang tua serta hubungan yang tidak harmonis dengan teman dan guru ikut menyebabkan adanya pengalaman negatif pada partisipan. Menurut Diener, (2009) Adanya 
pengalaman negatif disebabkan oleh ketidakpuasan individu terhadap situasi di sekitarnya. Temuan ini dijelaskan oleh Stillman \& Stillman (2018) yang menyebutkan adanya rasa ingin tahu yang tinggi, up to date terhadap informasi terbaru dan keinginan untuk mengeksplor dunia sosial yang lebih luas membuat generasi $Z$ cenderung akan mencari kepuasan terhadap kebutuhannya.

Kepuasan hidup ketiga partisipan dipengaruhi oleh capaian rangking di kelas, partisipan yang memperoleh rangking 1 di kelas merasa puas akan capaian tersebut, sebaliknya partisipan yang hanya memperoleh rangking 35 di kelas dari 45 siswa merasa tidak puas dengan capaiannya tersebut, kepuasan hidup lainnya dipengaruhi oleh jumlah hafalan yang diperoleh setiap partisipan, partisipan 1 dan 3 memiliki kepuasan terkait hafalan Al Qur'an karena sudah selesai menghafal 30 Juz, sebaliknya pada partisipan 2 belum merasa puas terkait hafalan Al Qur'an karena belum khatam sampai sekarang. Tidak tercapainya kepuasan hidup disebabkan tidak tercapainya tujuan yang diharapkan. (Diener, Lucas \& Oishi, 2003).

Faktor yang mempengaruhi well being ketiga partisipan dipengaruhi oleh keberhasilan menghadapi beban akademik, seperti menyelesaikan tuntutan menghafal Al Qur'an dan kitab salaf sebagai syarat kenaikan kelas, adanya support dari orang tua ke partisipan dalam menjalani kehidupan di pesantren, terjalinnya relasi positif antara partisipan dengan teman sesama santri dan guru, ustadz di pesantren, faktor tujuan hidup yang spesifik baik tujuan jangka panjang dan jangka pendek dan kemampuan partisipan untuk mewujudkannya. Faktor well being tersebut didukung oleh Diener, (2009) yang menyebutkan well being dipengaruhi oleh perbedaan jenis kelamin, tujuan hidup yang jelas dan kemampuan untuk mewujudkannya, kualitas spiritual, hubungan sosial yang positif, dan faktor kepribadian. Dampaknya partisipan yang memiliki pengalaman positif cenderung memiliki karakteristik patuh terhadap aturan pesantren dan memiliki prestasi akademik. Sedangkan partisipan dengan pengalaman negatif cenderung berperilaku melanggar aturan pesantren dan memiliki prestasi akademik yang rendah.

Tabel 2. Temuan penelitian

Faktor $\quad$ 1. Adanya support Orang tua.

Eksternal 2. Adanya relasi positif dengan teman dan guru (ustadz).

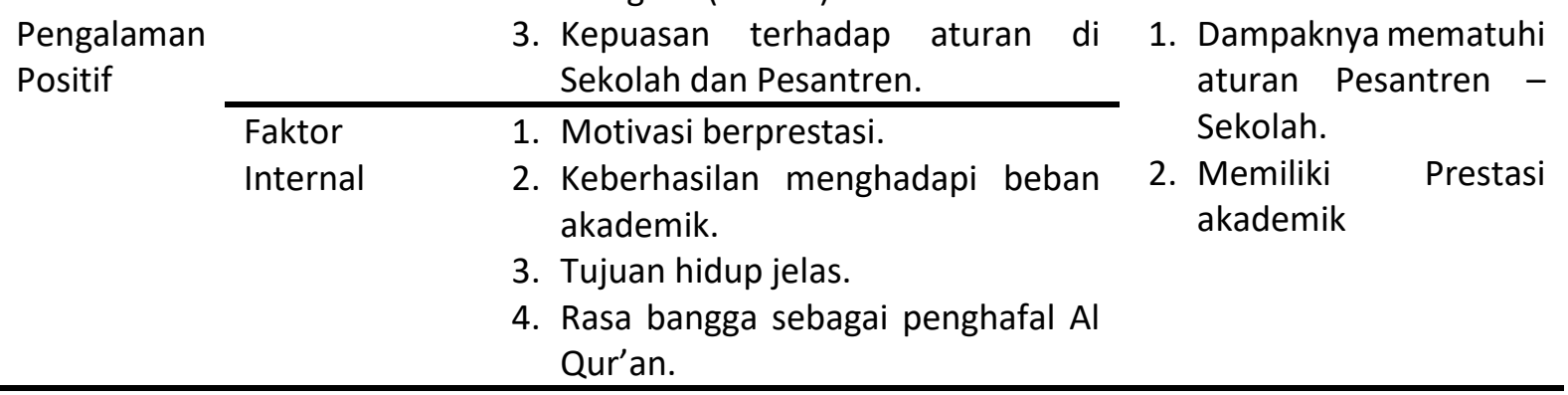

Faktor 1. Kurangnya support orang tua.

Eksternal 2. Relasi dengan teman dan guru (ustadz) kurang baik.

Pengalaman

Negatif
3. Tidak adanya kepuasan terhadap aturan di Sekolah dan Pesantren.

Faktor $\quad$ 1. Motivasi berprestasi rendah.

Internal 2. Tidak mampu menyelesaikan beban akademik.

3. Tujuan hidup belum jelas.
1. Dampaknya melanggar aturan sekolah- pesantren.

2. Prestasi akademik rendah. 


\section{Kesimpulan}

Hasil penelitian menunjukkan terdapat partisipan yang memiliki pengalaman positif maupun pengalaman negatif. Pengalaman ini dipengaruhi oleh faktor eksternal dan internal dalam diri. Faktor internal yang mendukung adanya pengalaman positif meliputi: adanya motivasi berprestasi yang tinggi, kemampuan partisipan dalam menghadapi beban akademik, adanya cita-cita dan tujuan hidup jelas yang ingin diraih serta perasaan bangga sebagai santri penghafal Al Qur'an. Faktor eksternal yang mendukung adanya pengalaman positif meliputi adanya dukungan dari orang tua, terjalinnya relasi positif pada partisipan dengan teman dan guru, serta adanya kepuasan dan perasaan bangga terkait kebijakan yang diterapkan Sekolah dan Pondok Pesantren. Pada pengalaman negatif faktor internal yang mendukung meliputi: rendahnya motivasi berprestasi, faktor ketidakmampuan partisipan dalam menghadapi beban akademik serta belum adanya cita-cita dan tujuan hidup yang jelas. Faktor eksternal yang mendukung adanya pengalaman negatif pada partisipan meliputi: kurangnya support dan perhatian dari orang tua, kurang terjalinnya relasi positif antara partisipan dengan teman dan guru, tidak adanya kepuasan terkait kebijakan yang diterapkan Sekolah dan Pondok Pesantren. Dampaknya partisipan yang memiliki pengalaman positif cenderung berperilaku sesuai peraturan di Sekolah dan Pondok Pesantren serta memiliki prestasi akademik yang bagus, sedangkan partisipan yang memiliki pengalaman negatif cenderung memiliki prestasi akademik yang rendah dan berperilaku melanggar aturan di Sekolah maupun Pondok Pesantren.

\section{Daftar Pustaka}

Arwaniyyah.com 2020 http://arwaniyyah.com/profil/?kategori=Pendidikan\&unit=12_di akses pada 15 September 2021.

A'yun, M. Q., Tentama, F., \& Situmorang, N. Z. (2018, September). Gambaran subjective well being pada remaja perempuan di pondok pesantren. In Temu Ilmiah Psikologi Positif I. Seminar dan Call for Paper" Positive Psychology in Dealing with Multigeneration". Universitas Pertamina Jakarta.

Bencsik, A., Horváth-Csikós, G., \& Juhász, T. (2016). Y and Z Generations at Workplaces. Journal of Competitiveness, 8(3). DOI: 10.7441/joc.2016.03.06

Boyatzis, R. E. (1998). Transforming qualitative information: Thematic analysis and code development. sage.

Csobanka, Z. E. (2016). The Z generation. Acta Technologica Dubnicae, 6(2), 63-76. DOI: 10.1515/atd2016-0012

Dewi, L., Tentama, F., \& Diponegoro, A. M. (2021). Subjective well-being: Mental health study among student in the Islamic boarding school. International Journal of Public Health, 10(1), 146-158. DOI: 10.11591/ijphs.v10i1.20610

Diener, E. \& Tov, W. (2013). Subjective well-being. Research Collection School of Social Science, Vol. 63, 421-440

Diener, E. (2009). Positive psychology: Past, present, and future. Oxford handbook of positive psychology, 2, 7-11. 
Diener, E., \& Suh, E. M. (2000). Measuring subjective well-being to compare the quality of life of cultures. Culture and subjective well-being, 3-12.

Diener, E., Lucas, R. E., \& Oishi, S. (2002). Subjective well-being: The science of happiness and life satisfaction. Handbook of positive psychology, 2, 63-73.

Fudyartanta, K. (2017). Pengantar psikodiagnostik.Yogyakarta: Pustaka Pelajar.

Hamdana, F., \& Alhamdu, A. (2015). Subjective Well-Being Dan Prestasi Belajar Siswa Akselerasi Man 3 Palembang. Psikis: Jurnal Psikologi Islami, 1(2), 115-124.

Hamdana, F., \& Alhamdu, A. (2015). Subjective well-being siswa MAN 3 Palembang yang tinggal di asrama. Psikis: Jurnal Psikologi Islami, 1(1), 95-104.

Liamputtong, P. (2009). Qualitative research methods.

http://statistik.data.kemdikbud.go.id/index.php/page/sma diakses pada 13 September 2021.

Neuman, W. L. (2013). Social research methods: Qualitative and quantitative approaches. Pearson education.

Rahmi, F., Hasnida, R., \& Wulandari, L. H. (2019). Effect of Academic Resilience on Subjective WellBeing of Students in Islamic Boarding Schools. International Research Journal of Advanced Engineering and Science, Volume 4, Issue 3, pp. 347-349, 2019.

Santrock, J. W. (2012). Life Span Development: Perkembangan Masa Hidup Jilid I.(B. Widyasinta, Penerj.) Jakarta: Penerbit Erlangga.

http://20317805.siap-sekolah.com/data-siap/siswa-daftartingkat/ diakses pada 13 September 2021

Stillman, D. \& Stillman, J. (2018). Generasi Z: Memahami Karakter Generasi Baru yang Akan Mengubah Dunia Kerja, (Edisi 1). Jakarta: Gramedia.

Yuliyanto, A., \& Indartono, S. (2019). The Influence of Spiritual Quotient Toward Subjective Well-Being of Student of Muhammadiyah Boarding School Yogyakarta High School. International Journal of Management and Humanities (IJMH). DOI: 10.35940/ijmh.L0342.0831219 